\title{
Community: a powerful label? Connecting wind energy to rural Ireland
}

\author{
Bríd Walsh*
}

\begin{abstract}
Much of the research on the social sustainability of renewable technologies has focused on local acceptance issues, community benefits from exogenous developments, and matters related to the planning and development process. Grassroots-initiated wind energy schemes as a form of rural enterprise have received less attention, especially in the Irish context. Using a case study approach, this paper analyses the challenges and opportunities faced in progressing community wind energy projects in rural Ireland. Such an analysis is especially relevant given Ireland's commitment to developing a fair and sustainable society as advocated in its Sustainable Development Framework. With the decline of agriculture and considerable outmigration from rural areas, wind energy represents an opportunity to revitalize rural economies. More generally, as opposition to wind turbines and associated infrastructure is common in Ireland, it is clear that the relevant authorities must engage local stakeholders more meaningfully in the planning and development process. In this vein, community energy initiatives have the potential to boost rural economies, enhance acceptance, and develop knowledge networks at the local level. Drawing lessons from a community wind energy case study, it is argued that community projects can be nurtured in Ireland by (i) engaging communities, especially weak stakeholders, in both agenda setting and the planning and development process for individual projects, and (ii) ensuring that technical and financial support is available to communities, while (iii) being careful to apply the 'community' label only to initiatives that can meet the expectations of such a project.
\end{abstract}




\section{Introduction}

Most research on wind energy in Ireland to date has focused on transitioning to a $100 \%$ renewable energy system (Connolly et al., 2011), public perceptions of wind power (Warren et al., 2005), and the feasibility of hybrid energy options (Goodbody et al., 2013). More generally, research on understanding the formation of local perceptions of community wind farms (e.g. Warren and McFadyen, 2010) has received less attention in the literature in favour of studies exploring public attitudes towards commercial wind farms (e.g. Bidwell, 2013; Eltham, Harrison, Allen, 2008; Swofford and Slattery, 2010; Warren and McFadyen, 2010; Wolsink, 2007). A general finding that grassroots engagement can increase local acceptance of energy infrastructure has emerged from these works. Community-initiated energy developments as an alternative rural enterprise in the Irish context have received little attention in the literature, and in practice few communities and local individuals have taken the initiative to develop wind energy independently. From a rural development perspective, the European Commission aims to promote community ownership, build capacity, and stimulate innovation through their Community-led Local Development Cohesion Policy 2014-2020 (European Commission, 2013). Likewise, the Irish Government has set its sights upon developing sustainable rural communities by increasing community and government (local and national) cooperation (DECLG, 2012). This paper explores the factors that shape local perceptions of a community wind farm in rural Ireland and suggests extensions to the best practice approaches advocated in the energy White Paper (2015) and the National Economic and Social Council's (NESC, 2014) report on community engagement in the wind industry.

Wind energy currently contributes $\sim 16 \%$ to Ireland's electricity supply (IWEA, 2015) with over 100 operational wind farms, including several small-scale initiatives under $1 \mathrm{MW}$. A majority of these projects were developed by corporate interests in relative isolation from local communities. Joint ownership arrangements between citizens and wind energy developers do occur but are not a common feature within the Irish wind sector. This paper draws upon interview data derived from sixteen interviews conducted across various stakeholder groups engaged in the Irish wind industry between 2009 and 2010. An inductive grounded theory methodology was used to collect and analyse the data. The grounded theory approach involved multiple iterations of data collection and analysis. Through this approach, key stakeholders with specific characteristics and experience were identified including developers (eleven interviewees), government/agency officials (one interviewee), local community members (three interviewees), and local authority planners (one interviewee). Interviewees 
are identified by their primary role to ensure anonymity. Following data collection, the data were then coded using open, axial, and selective coding techniques.

\section{Constructing community energy: the research and policy context for wind energy}

Walker and Devine-Wright (2008) define community projects as those where communities have a high degree of ownership and control, as well as sharing in economic gains. This far exceeds communities' main expectation, which is to be consulted on proposed projects (Rogers et al., 2008). As we transition to a low-carbon economy, new values will be attached to remote rural landscapes that offer opportunities for renewable energy production (Bridge et al., 2013; Howard et al., 2009). Community models are championed due to their potential to generate stable revenue (Hain et al., 2005), local support (Toke, 2005; Slee, 2015), and diversify local economies (Sawin, 2004), while nurturing energy citizenship (Slee, 2015), and a sense of connection within communities (Warren and McFadyen, 2010). Such connections are shaped by 'symbolic, affected and socially constructed aspects', and not just by financial gain, suggesting that communities may assume a psychological sense of ownership of such projects stemming from pride or sense of achievement (Devine-Wright, 2005; Warren and McFadyen, 2010, p. 6). Finally, as many countries have reduced public expenditure in line with the global recession, community ownership of renewables offer a means to bridge the funding gap at local level (Slee, 2015).

Despite increased interest in community-based energy models, there is little clarity as to what constitutes 'community' renewable energy (DevineWright and Wiersma, 2013; Walker et al., 2010). This fuzziness is problematic as the success of collective initiatives is influenced by the extent to which people form a community (Ostrom et al., 2002; Pretty 2003). Cohen (1985, p. 16) indicates that the primary element of community is that its members make, or believe they make, a similar sense of things... and further, that they think that that sense may differ from one made elsewhere'. This concept is linked to the notion of rootedness that relates to an emotional attachment to place, shared values, familiarity, and identity as 'individuals strive for a sense of spatial belonging' and create a deep sense of knowledge of their surroundings conditioned by factors such as religion and kinship ties (Lev-Wiesel, 2003; O'Rourke, 2005). As the community embodies 'the site of collective and cooperative activity' (Walker et al., 2010 , p. 2657), there is an assumption that local initiatives are inherently effective and socially sustainable. However, narratives of alienation and instances of "community either not really existing...or as fractured between 
those that are 'in' and 'out'" are reported in the literature (ibid, p. 2657). More generally, there is often a poor understanding of the form and purpose of grassroots initiatives at all governance levels, with the result that local authorities or other public organisations are uncertain how to support them, which hinders a move towards 'models of meaningful grassroots dialogue within enabling institutions' (O'Rourke, 2005, p. 496). Despite this uncertainty, it is clear that communities should have access to expertise from a 'trusted resource base' to stimulate and shape local energy projects (Letcher et al., 2007).

Slee (2015) and NESC (2014) categorize local ownership of wind energy developments as community, cooperative, and joint venture. As regards community ownership, models range from $100 \%$ community owned (e.g. Gigha, Scotland) to co-ownership arrangements with local citizens holding a significant share of equity (e.g. Templederry Wind Farm, Ireland), extending to local councils holding a share of equity such as in the case of Germany and Denmark (NESC, 2014; Slee, 2015). Most of the profits remain in the local community under such arrangements. While the majority of these equity-share schemes are developer led, some are 100\% community owned such as the Islay Energy Community Benefit Society which raised $£ 535,000$ through equity-share offers to fund the Islay Community Wind Project (NESC, 2014; IET, 2014). Recently, a sum of $£ 60,000$ was transferred to the Islay Energy Trust to support renewable, insulation, and energy efficiency schemes (IET, 2011). Another case involves the quick sale (13 hours) of $€ 1.3$ million worth of shares in a wind energy project to $~ 1700$ Dutch households via a crowd-funding scheme (NESC, 2014). Cooperative ownership is marked by a structure where members of the public (not necessarily local stakeholders) may purchase equity shares and receive interest on their investment such as the Drumlin Wind Energy Cooperative in Northern Ireland. Finally, joint ventures involve collaboration between a commercial developer and a community organization (NESC, 2014). For example, an extra 'community' turbine was added to the Earlsburn Wind Farm in Scotland, with the developer bearing the initial costs of the turbine, which will be paid back by the community over a 15 -year period (Ibid).

Within this broad framework, the ownership models outlined above are increasingly including a community fund as a development provision wherein a portion of project profits are made available to support local development (Aitken, 2010; Munday, Bristow, Cowell, 2010). In the United Kingdom, such funds are administered via Community Interest Companies usually controlled by local stakeholders such as Fullabrook Community Interest Company that administers a fund of over $£ 1$ million (FCIC, 2016). Fears on the part of developers that such funds may be perceived as a form of buying consent have led to wariness of these instruments (Aitken, 2010), 
especially in the case of commercial projects and contentious community developments. To allay these fears and ensure consistency across projects, community gain provisions are now part of the development process in several countries (such as Denmark and Germany) through legal/financial instruments such as tax breaks for community members (DTI, 2005). Such provisions are not currently part of Irish energy policy.

\section{Policy support for community wind energy development in Ireland}

To date, Irish national policies such as the Strategy for Intensifying Wind Energy Deployment (2000) and the Green Paper on Energy Policy in Ireland (2014) have not meaningfully advocated community development models for wind energy. Although the Green Paper highlights the importance of empowering energy citizens, this is largely understood as supporting energy savings schemes and decarbonizing homes rather than championing community ownership of renewable schemes. More recently, the White Paper on Ireland's Transition to a Low Carbon Energy Future 2015-2030 suggests a move from passive to active citizen engagement, especially with regard to solar photovoltaic and wind energy. In this vein, the State will fund and support community-initiated projects during the initial period of planning and development, facilitate grid access and payment for electricity generation, as well as develop a framework to ensure community benefits from energy infrastructure in their localities. In an encouraging move, it seems this policy is drawing on the Danish Renewable Energy Act (2009) which mandates a guarantee fund to support scoping exercises at the early stages of development, mandatory share ownership for communities, and a green scheme provision, which subsidises activities that promote local renewable projects. These national policy and planning objectives are implemented at the local level through guidelines found in county development plans. Reflecting a policy gap, the county development plans do not promote community ownership models for wind energy in a meaningful or consistent manner with just eight of a total of twenty-eight plans encouraging community ownership. Community economic gains via investment and/or community funds are advocated in just four plans.

There are several small-scale community wind farms in Ireland including Templederry Community Wind Farm, which began producing electricity in 2012 (4.60 MW; cost €6.2 million; population 900). The project has four directors and approximately thirty shareholders with one share held by the Tipperary Energy Agency (county-level agency) and two shares created for the wider community (Kenny, 2015). It serves as an example of a successful 
community project, with strong community-wide local support (i.e. few objections submitted to the local planning authority) (NESC, 2014). Back in 1999, the Templederry Community Group drafted a Community Development Plan, funded through the county LEADER Group (an initiative to support rural development), which identified renewable energy as a potential source of income for their community. The Tipperary Energy Agency provided key financial and technical support services (NESC, 2014). All community members were afforded the opportunity to invest, and landowners with a turbine on their land received an annual rent. The wider community are involved through a community fund which supports social housing developments and energy efficiency measures in homes, for example.

This paper offers insights on the factors that shape community perceptions of community wind projects, with specific reference to a project in the West of Ireland, and adds to the literature on best practice approaches to community energy development. This research is guided by the following two questions:

- What factors are influential in explaining community perceptions of a specific community wind farm?

- What steps can be taken to increase community engagement in such projects?

\section{Results}

The interview data suggest scepticism regarding the future of community wind energy in Ireland, especially given the (i) financial challenges (e.g. one interviewee remarked that the capital required would be substantial and it would be too much for our small group to handle without taking a major investor on-board or selling it off' [Interview; developer 1], while another argued that 'the days of the small operators are gone, everything has gone too expensive' [Interview; developer 2]), (ii) mobilization challenges (e.g. maintaining community momentum and the need to 'paddle your own canoe' [Interview; developer 3] in a long planning process), and (iii) technical challenges (e.g. securing a grid connection and the need for 'hardnosed business analysis' to progress projects [Interview; developer 4]). As one interviewee puts it, 'you may see one or two [projects], they will come from a couple of extraordinary people who would have given very generously of their own time and expertise' (Interview; developer 4). The following case study demonstrates the challenges associated with advancing a community project in the Irish context. 


\section{Community wind energy: a case study}

The project involves the development of a $\sim 80 \mathrm{MW}$ cooperative partnership wind energy project in a rural area in the West of Ireland, with a goal of engaging the wider local community through investment opportunities and a community fund. Planning permission was granted in 2011, following an appeal to An Bord Pleanála (third party planning appeals board). The project is currently awaiting a connection to the national electricity grid.

\section{Planning support and ownership structure}

The $€ 170$ million wind farm was progressed through a limited company with four directors, and shares held by over thirty landowners covering an area of 3500-4000 acres of land. Of these landowners, twenty-four live in the local area. Initially, a group of seven landowners investigated the possibility of developing wind energy in their locality, motivated by 'a desire to hand on viable farms to the next generation..[and secure] supplementary income' (Interview; developer 5). Following kitchen table meetings with landowners, the initial group of seven grew to a group of thirty. All thirty landowners were not engaged in the project in a decision-making capacity with key decisions regarding financing, ownership structure, and turbine placement taken by the directors in consultation with relevant experts. It was reported that eight to ten meetings were held which included most of the thirty landowners, with 'plenty of friction' (Interview; developer 5) reported at some of these meetings caused by disagreements on organizational and financial aspects. Such disagreements were successfully mediated by the group itself; however, informal meetings where landowners meet each other socially were considered most effective at achieving consensus.

Three of the four directors were 'local to the area or [county]' (Interview; developer 5). One of the directors is a wind energy developer. Another is the landowner representative whose role is to liaise with his neighbours and tell them what's going on' (Interview; developer 5). All thirty landowners with shares in the project had to commit from day one and agree to put their land forward, in return for a guaranteed payment equivalent to $1 \mathrm{MW}$ capacity. Several individuals with large landholdings invested in the project at an early stage, and represent the majority shareholders. Members with smaller landholdings were allocated shareholdings without having to invest in the project. Approximately $10 \%$ of the project is designated for wider local investment. Finally, a community fund distributed through a municipal budget model to the four local parishes will be available to support local projects once the wind farm is operational.

The Regional Energy Agency was cited as providing a good source of support. The project did not receive funding to aid preliminary investigations 
from any government agency. The directors engaged in one-to-one preplanning meetings with the local planning authority, which were considered useful as they 'highlighted potential areas of concern that would merit more extensive study' (Interview; developer 5). In general, the local authority was deemed to be 'fairly strongly behind the idea' (Interview; developer 5).

The project received significant local and national press coverage between 2009 and 2011. A public consultation evening was held in December 2009, which was advertised in local newsletters five days in advance. Over 200 citizens attended. Local financial gain provisions were outlined at this meeting, including the investment opportunities and community fund. Following this meeting, and with a goal of addressing local concerns, the project directors 'held over ten one-to-one meetings with local objectors and offered an open door to them privately and publically' (Interview; developer 5). It was acknowledged that public consultations were undertaken one month prior to lodging the planning application, but it was emphasized that the intention was not to keep the project a secret:

We never kept anything secret [...] a lot of people knew something was happening but not quite what, so we unveiled our plans (Interview; developer 5).

Finally, there was a lack of consistency in the categorization of the project. It was referred to as a cooperative partnership in the planning application, while in the media it was called both a community wind farm and a cooperative, whereas the official planning notice in the local newspaper did not refer to it as either.

\section{Local opposition}

Upon publication of the plans, a group of over thirty community members objected to the proposal on several environmental and social grounds. It was stressed in the community interviews that the 'community' label inaccurately represented the project, with one interviewee categorizing it as 'callously capitalistic' (Interview; community 1):

It is the opposite of a community project. The only people involved are the developers, the farmers, and non-resident landowners. It has been completely divisive to the community and has created a great deal of distress for the people who are not involved (Interview; community 2)

That the project leaders 'disseminated information' (Interview; community 2) rather than undertaking meaningful, transparent consultation with all stakeholders was also put forward as influential in explaining local opposition. Some reported feeling alienated and noted the divisive nature of the consultation process in particular: 
We live within $1 \mathrm{~km}$ of at least five of the proposed turbines. We were never contacted by the developers. We were lucky to hear about it in time to submit an objection to the planning application (Interview; community 1).

Once the directors became aware of the local opposition, they extended invitations to meet with those opposing the project, which led to a few members of the opposition group joining the project. Others viewed such offers of participation at such a late stage as vacuous and not in line with the spirit of a community project. Indeed, the directors acknowledged in retrospect that engaging the wider community earlier by consulting 'one-to-one, or house to house within one to two kilometres of the site' (Interview, developer 5) would have been a more effective strategy. A clear disparity exists between what community members expected from the project and the reality of what was delivered. One interviewee emphasized that:

Any community windfarm would have made a point of significant community outreach to affected households in the planning phase, would have worked to ameliorate neighbours' concerns, and would have made a point of informing the community, rather than keeping information from us (Interview; community 1).

With questions relating to what constitutes a 'community' project featuring strongly in the interview data, criticism is levelled against national government for failing to define 'community' for wind energy purposes in a functional and operationally friendly manner within Irish policy guidelines. There was also considerable scepticism as to the benefits flowing from the project, as one interviewee points out:

The proposed development [was] put together by outside developers with little interest in the area, who make use of local landowners, and who will sell the development on to multinational energy companies at the drop of a hat. If anyone benefits from such a development, it will not be the community (Interview; community 1 ).

In line with this, strong emphasis was placed on the need to embed sustainable energy within Irish communities by considering 'all residents as stakeholders in the enterprise', gathering 'support from a majority of local landowners', ensuring 'transparency in all negotiations', and championing 'philanthropy that benefits the community equitably' (Interview; community 1) such as through energy saving schemes that benefit all community homeowners. The need for 'total transparency as to long term proposals for the area' was also highlighted (Interview; community 2). Finally, and in addition to the dissatisfaction regarding benefits, consultation, and labelling of the project as 'community', a further source of frustration was evident: disappointment regarding the role of local elected representatives as a conduit to engaging in local planning issues was reported with county councillors 
deemed unwilling to 'represent our concerns in the council chamber' (Interview; community 3).

\section{Discussion}

Sustainable infrastructure projects require a 'social license' to operate (Corscadden, Wilde, Yiridoe, 2012), with an emphasis on increasing consultation at local level. The case study explored in this paper represents one of the first attempts to embed large-scale renewables as a rural enterprise in Ireland and presents important lessons regarding the operational framework for community models. The project faced considerable local opposition and does not measure up too well as an inclusive, participative community initiative owing to the exclusion of weak stakeholders (i.e. those stakeholders with interests to protect, but with limited capacity to do so [Baraud et al., 2014]), lack of a community involvement in policy agenda setting, insufficient consultation during the project planning process, lack of technical and financial support, and diverging constructions of what constitutes a community project. There are two broad areas that need more attention to foster a community wind energy sector in Ireland: (i) use of the 'community' label and (ii) embedding 'community' within community wind farms.

\section{'Community': a powerful label?}

There are numerous ways in which communities may be involved in wind farms, and clear distinctions must be made to ensure local expectations are matched by experiences. In this case study, inconsistent categorization of the project was problematic, i.e. definitions ranged from cooperative partnership to community project to the absence of either definition in some documentation. This contributed to community interviewees questioning the structure and intent of the project suggesting that a project with a combination of farmer and non-resident landowner participation does not automatically grant community status to the project. Applying the 'community' label produces certain expectations regarding the form and function of the development process, specifically the meaningfulness and scale of community involvement. As Walker and Devine-Wright (2008, p. 499) remind us 'there is something significant and important about a community approach to renewable energy that is lost when projects are labelled community', but are not as open and participatory as a community label presupposes. The case study highlights that communities and external agents (public authorities and developers) can have different expectations of a community project, and there is a danger in applying the community label to a project that 
does not live up to the vision of the community in question, or subsets thereof. The misuse of the label may be related to the policy signal that community projects should be championed and supported, and thus that planning authorities may look upon such applications more favourably. This was highly influential in explaining local opposition in the case study and is in line with scholarly discussions on community renewables (Aitken, McDonald, Strachan, 2008; Walker et al., 2010). Furthermore, Devine-Wright and Wiersma (2013, p. 1101) argue that we must deepen our understanding of the 'situatedness' of the stakeholders, i.e. what constitutes a 'local' stakeholder? In the Irish case, while community stakeholders expected widespread inclusion of all local residents, the project directors and local planning authority considered the involvement of thirty landowners as sufficient for the project to qualify as a 'community' initiative. Interestingly, this is not to be interpreted solely as conflicting endogenous and exogenous interpretations of 'community', but represents differing understandings of what 'local' meant within the community itself as the lead project directors were also members of that community.

Embedding wind energy as a community entrepreneurial exercise speaks to the broader desire to maintain the viability of rural living, as well as preserving the socially constructed community identity. As O'Rourke (2005, p. 487) reminds us, 'the concept of community is inseparably tied to that of identity'. In recent years, agriculture has been experiencing a progressive decline as the primary rural economic activity in Ireland (Champion and Brown, 2012). Rural areas have also endured considerable outmigration (Cairns, 2014) and population decline (particularly along the West coast). The interview data signal an almost protectionist attitude from one of the project directors in terms of ensuring local opportunities for younger generations via the project; however, this goal was not linked to the continued prosperity of the community as a whole. As regards economic benefits, expectations of community-wide gains such as energy savings schemes for all homes, were evident in the interview data. This call is in line with the experience of the Templederry project where community benefits were successfully used for collective purposes, e.g. social development housing. Accordingly, community schemes must be wary of taking engagement practices from commercial projects (e.g. investment opportunities and community funds) and applying them directly to community projects, without supplementing such offers with collective, inclusive initiatives that nurture energy citizenship.

Embedding 'community' within community wind farms

Several factors are influential in explaining why there are few community wind energy developments in Ireland. Firstly, communities are not 
involved in agenda setting at a policy and planning level. Secondly, the planning process is time and resource intensive and requires considerable outside expertise for preparing environmental impact assessments, for example. Community interviewees argued that national policy should support and guide local wind energy projects. Although this could contribute to uniformity and clarity for communities and fill the gap between expectations and experiences, a more important action is to embed 'community' within such projects at local level by embedding environmental justice principles such as participation (i.e. to meaningfully take part in the planning and development process), equity (i.e. to have an equal and fair opportunity to participate), and inclusivity (i.e. to include all community members regardless of status, landownership, etc.) (Schlosberg, 2013) within rural energy planning. In this vein, the results highlight three key areas for improvement: (i) community engagement in agenda setting or visioning, (ii) community engagement in project planning and development, and (iii) provision of technical and financial support. Each will be discussed in turn with specific reference to the recent White Paper on Ireland's transition to a low-carbon future (DCENR, 2015) and the NESC (2014) report on community engagement with wind energy.

\section{Engagement in agenda setting or visioning}

Ireland's most recent energy White Paper (DCENR, 2015) does not mention community involvement in agenda setting as a policy goal, but does argue for an 'effective and inclusive process of public participation that helps to shape and share local value' (ibid, p. 42). To avoid one-size-fits-all interpretations of 'community', emphasis should be placed on engaging communities in agenda setting or visioning. In practice, this would involve action at both local level in the first instance and regional or national level in the second. At local level, a community energy development plan would be created by local stakeholders, as took place in the Templederry case, but not in the West of Ireland case study. This type of planning would identify the community profile, potential projects, and required support structures, while reflecting the fact that boundaries of communities as defined by locals far better embody the community as compared to administrative boundaries or lines drawn by outside authorities. This would allow a deeper understanding of how the local and regional space is constructed and experienced, while enhancing plan-led renewable development, which Harvey and Moloney (2013) argue has been lacking in the Irish context. Positively, precedent already exists for such actions in the Irish planning sector. For example, Mayo County Council supports communities to create Community Action Plans under a scheme called 'Mayo Community Futures'. 
With a community development plan in place, supportive action at either regional or national level would follow, where authorities work within the framework developed by the communities. This approach would ensure that a community label could only be used in cases where locals have developed and endorsed a community development plan. Once meaningful and inclusive, this process would reduce the likelihood of community fracture between those 'in' and 'out' of community initiatives (Walker et al., 2010, p. 2657). This agenda setting approach has the potential to stimulate a perception of (real or imagined) interconnectedness promoted, (often) unconsciously, as stakeholders discuss their concerns and work towards uncovering mutually acceptable solutions (Innes and Booher, 2003). It would also facilitate the inclusion of weak stakeholders including (i) those with land neighbouring proposed projects but with no direct involvement, (ii) residents living in close proximity to proposed projects, and (iii) all community members who took part in producing the community energy development plan, but have no role in specific projects.

\section{Engagement in project planning and development}

Clear offers to participate in both agenda setting and the project development process should be made to all local stakeholders, with a goal of avoiding, as far as possible, the creation of winners and losers (Gross, 2007). This could go a long way towards transforming the rural experience with development practices, and reimagining the relationship communities have with the natural resources available to them. As Rogers et al. (2008) remind us, currently communities' main expectation is to be consulted about proposed projects. We see this community desire directly reflected in both the White Paper (DCENR, 2015) and the case study. The White Paper, for example, has established a National Energy Forum to enhance consultation by bringing together diverse stakeholders including community representatives, to discuss broad energy policy issues. In the case study, community members called for greater consultation, especially those who were not financially involved as they felt a sense of powerlessness, and an inability to establish their identities as stakeholders and shepherds of development in their locality. As a result, a large section of the community felt alienated by the planning process, which Lev-Wiesel (2003, p. 334) reminds us 'is regarded as opposite to rootedness and a psychological sense of community'. This is critical to understanding why the community fractured in the case study. Although attempts were made to engage all locals, i.e. a well-attended public consultation event took place, the event was held long after the project parameters were established and functioned as an information provision exercise. That is not to say that iterative 
dialogue did not take place during the course of this project. In fact, two separate arenas of networking were identified between (i) those directly involved in the project through turbine placement and investment, and (ii) those in opposition.

\section{Technical and financial support}

While the White Paper (DCENR, 2015, p. 43) states that the 'emerging energy cooperative movement' will be supported, it does not elaborate on the form or function of these supports. Expertise from a 'trusted resource base' (Letcher et al., 2007) should be available to communities during both the agenda setting and the planning and development phase to aid in the preparation of grid connection applications, for example. This worked well in the Templederry project but was notably absent in the case study. Such technical support could be profitably deployed through local development organizations or as the White Paper (2015) suggests through regional divisions of the Sustainable Energy Authority of Ireland (SEAI) and NESC. Ireland has a strong tradition of using local partnerships to address rural development challenges and fill a void left by weak local government (Moseley, Cherrett, Cawley, 2001). In this tradition, local development organizations, working in conjunction with local energy agencies, could act as intermediaries in providing support to local projects. This is in line with the goals of the White Paper (DCENR, 2015), i.e. to increase support for community-led projects, and NESC's (2014) call for increased cross-agency and community collaboration.

To bridge the capital gap encountered by communities in the early phase of wind development, a standardized approach for the provision of seed funding for initial scoping investigations by communities could also be implemented. This would follow the initial agenda setting phase, as discussed earlier in this section. In this vein, Ireland can draw from the guarantee fund provision of the Danish Promotion of Renewable Energy Act (2009). This fund is managed by Denmark's national transmission system operator, and it provides financial support to local groups (maximum DKK 500,000 per project) for preliminary site investigations. This financing is only available to groups with a controlling influence over proposed projects and with at least ten members (a majority of which must live in the municipality, or if outside the municipality at a distance of $<4.5 \mathrm{~km}$ from the site). In the Irish context, such a fund could be administered through the transmission system operator, Eirgrid, with communities retaining decision-making control over the allocated funds. The provision of technical and financial support, as outlined above, and increased community participation in agenda setting and in the planning process for specific 
projects would reflect 'a realization by State agencies and local communities that they can and must work together' (Moseley et al,, 2001, p. 186), while enhancing community control over infrastructure development decisions at local level.

\section{Conclusion}

Although the contribution of community-led wind energy developments may be small in terms of installed capacity, noteworthy benefits arise from such developments including contributions to the sustainable development of communities. Bottom-up renewable energy projects should be supported to complement the dominant exogenous approach in Ireland. Although genuinely collaborative energy projects that are empowering for communities are rare in Ireland, both national policy and the case study outlined above demonstrate that there is an appetite for community development models. Care must be exercised in applying the community label as it presupposes a project that is both for and by the community. Emphasis must be placed on both technical and financial support, as well as engaging communities in agenda setting via community development plans that account for local perceptions of what their 'community' means to them. Finally, all community wind farms should make unambiguous clear offers to participate to all local stakeholders and should not disenfranchise weak stakeholders, such as locals without landholdings and the ability to have a turbine placed on their land.

\section{Acknowledgements}

The author would also like to thank two anonymous reviewers for their useful comments.

\section{Funding}

Irish Environmental Protection Agency (EPA) STRIVE Doctoral Scholarship Scheme (Project number 2007-PhD-SD-1); the Department of Environment, Heritage and Local Government under the National Development Plan 2007-2013.

Bríd Walsh is an Assistant Professor in Energy and Environmental Change at Leiden University College, The Hague. 


\section{References}

Aitken, M., McDonald, S. and Strachan, P. (2008) Locating "power" in wind power planning processes: the (not so) influential role of local objectors, Journal of Environmental Planning and Management, 51 (6), 777-799.

Aitken, M. (2010) Wind power and community benefits: challenges and opportunities, Energy Policy, 38, 6066-6073.

Baraud, C., d'Aquino, P., Daré, W., et al. (2014) Power asymmetries in companion modelling processes, in Étienne, M., ed, Companion Modelling: A Participatory Approach To Support Sustainable Development, Springer, Netherlands.

Bidwell, D. (2013) The role of values in public beliefs and attitudes towards commercial wind energy, Energy Policy, 58, 189-199.

Bridge, G., Bouzarovski, S., Bradshaw, M., et al. (2013) Geographies of energy transition: space, place and the low-carbon economy, Energy Policy, 53, 331-340.

Cairns, D. (2014) "I wouldn't stay here": economic crisis and youth mobility in Ireland, International Migration, 52 (3), 236-249.

Champion, T. and Brown, D. (2012) Migration and urban-rural population redistribution in the UK and US, in M. Shucksmith, D. Brown, S. Shortall, J. Vergunst and M. Warner, eds, Rural Transformations and Rural Policies in the US and UK, Routledge, London, pp. 39-57.

Cohen, A.P. (1985) The Symbolic Construction of Community, Ellis Horwood Ltd. and Tavistock Publications Ltd, Chichester and London, UK.

Connolly, D., Lund, H., Matheisen, B.V., et al. (2011) The first step towards a $100 \%$ renewable energy-system for Ireland, Applied Energy, 88 (2), 502-507.

Corscadden, K., Wilde, A. W. and Yiridoe, E. (2012) Social license and consultation criteria for community wind projects, Renewable Energy, 44, 392-397.

DCENR (Department of Communications, Energy and Natural Resources) (2014) Green Paper on Energy Policy in Ireland, DCENR, Dublin.

DCENR (Department of Communications, Energy and Natural Resources) (2015) White Paper on Ireland's Transition to a Low Carbon Energy Future., DCENR, Dublin.

DECLG (Department of Environment, Community and Local Government) (2012). Our Sustainable Future: A Framework for Sustainable Development in Ireland, DCENR, Dublin.

Devine-Wright, P. (2005) Beyond NIMBYism: towards an integrated framework for understanding public perceptions of wind energy, Wind Energy, 8 (2), 125-139.

Devine-Wright, P. and Wiersma, B. (2013) Opening the the 'local' to analysis: exploring the spatiality of UK urban decentralised energy initiatives, Local Environment, 18 (10), 1099-1116.

DTI (2005) Community Benefits from Wind Power: A Study of Uk Practice and Comparison with Leading European Countries, accessed at: https://www.cse.org.uk/downloads/ file/community-benefits-wind-power.pdf (7 October 2016).

Eltham, D.C., Harrison, G.P. and Allen, S.J. (2008) Change in public attitudes towards a Cornish wind farm: implications for planning, Energy Policy, 36 (1), 23-33.

European Commission (2013) Community-led Local Development Cohesion Policy 20142020. European Commission, accessed at: http://ec.europa.eu/regional_policy/ sources/docgener/informat/2014/community_en.pdf (7 October 2016). 
FCIC (2016) About the Community Interest Company, accessed at: http:/ /www. fullabrook-cic.org/about.htm (29 April 2016).

Goodbody, C., Walsh, E., McDonnell, K.P., et al. (2013) Regional integration of renewable energy systems in Ireland - the role of hybrid energy systems for small communities, International Journal of Electrical Power and Energy Systems, 44 (1), 713-720.

Gross, C. (2007) Community perspectives of wind energy in Australia: the application of a justice and community fairness framework to increase social acceptance, Energy Policy, 35, 2727-2736.

Harvey, A. and Moloney, K. (2013) The Onshore Wind Farm Sector in Ireland: Planning in Harmony with Heritage, The Heritage Council, Kilkenny.

Hain, J.J., Ault, G.W., Galloway, S.J., et al. (2005) Additional renewable energy growth through small-scale community energy policies, Energy Policy, 33 (9), 1199-1212.

Howard, D., Richard, A., Wadsworth, J. W., et al. (2009) The impact of sustainable energy production on land use in Briatin through to 2050, Land Use Policy, 26S, S284-S292.

Innes, J.E. and Booher, D.E. (2003) Collaborative policymaking: governance through dialogue, in M.A. Hajer and H. Wagenaar, eds, Deliberative Policy Analysis: Understanding Governance in a Network Society, Cambridge University Press, Cambridge.

IET (2011) Islay Energy Trust, accessed at: https:/ / islayenergytrust.files.wordpress. com/2011/08/islay-energy-trust-introduction-aug-2011.pdf (29 April 2016).

IET (2014) Islay Energy Trust, accessed at: https:/ /islayenergytrust.org.uk/author/ islayenergytrust/ (7 October 2016).

IWEA (2015) Wind Energy Statistics, accessed at: http://www.iwea.com/_windenergy_ onshore (23 January 2015).

Kenny, P. (2015) Templederry community wind farm: lessons and visions. Tipperary Energy Agency, accessed at: http:/ / www.fedarene.org/wp-content/uploads / 2015/10/10-Manage-Energy-Templederry.pdf (28 June 2016).

Letcher, M., Redgrove, Z., Roberts, S., et al. (2007) Mobilising Individual Behaviour Change Through Community Initiatives: Lessons for Climate Change. Report by the Centre for Sustainable Energy (CSE) and Community Development Xchange (CDX) for DEFRA, Communities and Local Government, DTI, DfT and HM Treasury, accessed at: http:/ / www.cse.org.uk/pdf/pub1073.pdf (23 January 2015).

Lev-Wiesel, R. (2003) Indicators constituting the construct of perceived community cohesion, Community Development Journal, 38 (4), 332-343.

Moseley, M.J., Cherrett, T. and Cawley, M. (2001) Local partnerships for rural development: Ireland's experience in context, Irish Geography, 34 (2), 176-193.

Munday, M., Bristow, G. and Cowell, R. (2010) Wind farms in rural areas: how far do community benefits from wind farms represent a local economic development opportunity? Journal of Rural Studies, 27 (1), 1-12.

NESC (National Economic and Social Council) (2014) Wind Energy in Ireland: Building Community Engagement and Social Support. Dublin. NESC.

Ostrom, E., Dietz, T., Dolsak, N., Stern, P., Stonich, S. and Weber, E., eds. (2002) The Drama of the Commons, National Academy Press, Washington. 
O'Rourke, E. (2005) Socio-natural interaction and landscape dynamics in the Burren, Ireland, Landscape and Urban Planning, 70, 69-83.

Pretty, J. (2003) Social capital and the collective management of resources, Science, 302, 1912-1914.

Rogers, J.C., Simmons, E.A., Convery, A., et al. (2008) Public perceptions of opportunities for community-based renewable energy projects, Energy Policy, 36, $4217-4226$.

Sawin, J. (2004) National Policy Instruments: Policy Lessons for the Advancement \& Diffusion of Renewable Energy Technologies Around the World, Thematic Background Paper, Secretariat of the International Conference for Renewable Energies, Bonn.

Schlosberg, D. (2013) Theorizing environmental justice: the expanding sphere of a discourse, Environmental Politics, 22 (1), 37-55.

Slee, B. (2015) Is there a case for community-based equity participation in Scottish onshore wind energy production? Gaps in evidence and research needs, Renewable and Sustainable Energy Reviews, 41, 540-549.

Swofford, J. and Slattery, M. (2010) Public attitudes of wind energy in Texas: local communities in close proximity to wind farms and their effect on decision-making, Energy Policy, 38 (5), 2508-2519.

Toke, D. (2005) Community wind power in Europe and the UK, Wind Engineering, 29 (3), 301-308.

Walker, G. and Devine-Wright, P. (2008) Community renewable energy: what should it mean? Energy Policy, 36, 497-500.

Walker, G., Devine-Wright, P., Hunter, S., et al. (2010) Trust and community: exploring the meanings, contexts and dynamics of community renewable energy, Energy Policy, 28 (6), 2655-2663.

Warren, C. R., Lumsden, C., O’Dowd, S., et al. (2005) 'Green on Green': public perceptions of wind power in Scotland and Ireland, Journal of Environmental Planning and Management, 48 (6), 853-875.

Warren, C.R. and McFadyen, M. (2010) Does community ownership affect public attitudes to wind energy? A case study from south-west Scotland, Land Use Policy, 27 (2), 204-213.

Wolsink, M. (2007) Wind power implementation: the nature of public attitudes equity and fairness instead of 'backyard' motives, Renewable and Sustainable Energy Reviews, 11 (6), 1188-1270. 